Journal of Natural History, 1998, 32, 763-775

\title{
A cladistic revision of the genus Fredius (Crustacea: Decapoda: Pseudothelphusidae) and its significance to the biogeography of the Guianan lowlands of South America
}

\author{
G. RODRÍGUEZ and M. R. CAMPOS $\dagger$ \\ Instituto Venezolano de Investigaciones Cientificas, Apartado 21827, \\ Caracas 1020A, Venezuela \\ $\dagger$ Universidad Nacional, Instituto de Ciencias Naturales, \\ Apartado Aereo 53416, Bogotá, Colombia
}

(Accepted 16 October 1997)

\begin{abstract}
A revision of the cladistic analysis presented by Rodríguez and Pereira (1992) for the species of the genus Fredius Pretzmann, 1967 (Pseudothelphusidae), was carried out using additional species and new homologies to obtain a more robust cladogram. The tree obtained differs from the previous one in the clustering of species, but the area cladogram confirms a previous theory on the plausible evolution of the group in the Guianan lowlands of South America, between the Orinoco and the Amazon rivers. A new species is described from Colombia, extending considerably the range of the genus into the upper Amazon basin. A key to all species in the genus is given.
\end{abstract}

KeYwords: Pseudothelphusidae, freshwater crabs, phylogenetics, Guianas.

\section{Introduction}

Freshwater crabs, as have being pointed out by $\mathrm{Ng}$ and Rodriguez (1996), are very useful as biogeographical indicators. This is particularly true regarding the genus Fredius Pretzmann, 1967, due to the restriction of each species to a distinct hydrographic basin within the South American Guianas. Rodriguez and Pereira (1992) in their revision of the genus Fredius, presented a cladistic analysis of seven species of this group. Since then, a number of new laxa have been recognized, with the description of F. stenolobus Rodríguez and Suárez, 1994, the recent discovery of a new species from Colombia described in the present contribution, and the validation of $F$. fittkaui (Bott, 1969) as distinct from $F$. reflexifrons (Ortmann, 1897).

In the present contribution new homologies have been examined and the information in Rodrígucz and Pereira (1992) corrected and expanded to produce a more robust cladogram, and the most plausible evolutionary scenario for the group is reassessed. The species examined come from the territories of Venezuela, Guyana, Surinam, French Guiana, and Colombia. The material recorded is deposited at the Museo de Historia Natural, Instituto de Ciencias Naturales, Universidad Nacional de Colombia, Bogota (ICN-MHN) and at the Instituto Venezolano de Investigaciones Cientificas, Caracas (IVIC). The abbreviations cb. and cl. are used for carapace breadth and carapace length, respectively. 


\title{
Systematics
}

\author{
Family PSEUDOTHELPHUSIDAE Rathbun, 1893 \\ Tribe KINGSLEYINI Bott, 1970 \\ Genus Fredius Pretzmann, 1967 \\ Fredius granulatus sp. nov. \\ (figures $1 \mathrm{~A}-\mathrm{G} ; 2 \mathrm{C}, \mathrm{D}$ )
}

\section{Material examined}

Sitio La Sabana, Centro Providencia, Comunidad Makuna, Corregimiento La Pedrera, Amazonas Department, Colombia, $200 \mathrm{~m}$ alt., 15 November 1994, coll. M. R. Campos, 1 ơ Holotype, cl $44.0 \mathrm{~mm}$, cb $70.8 \mathrm{~mm}$ (ICN-MHN-CR 1429), 2

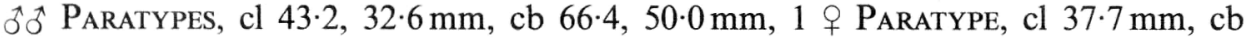
$58.6 \mathrm{~mm}$ (ICN-MHN-CR 1430, 1431), 1 ô PARATYPE, cl. $32.8 \mathrm{~mm}$, cb $50.7 \mathrm{~mm}$ (IVIC 943) - Sitio El Puerto, Comunidad Makuna, Corregimiento La Pedrera, Amazonas Department, Colombia, $180 \mathrm{~m}$ alt., 16 November 1994, coll. M. R. Campos, 1 ऽ, cl $38.7 \mathrm{~mm}$, cb $59.6 \mathrm{~mm}, 3$ \& , cl $34.5,33.2,32.1 \mathrm{~mm}$, cb $51 \cdot 3,49 \cdot 8,48 \cdot 1 \mathrm{~mm}$ (ICN-MHN-CR 1433).

\section{Diagnosis}

Cephalic lobe of first gonopod straight, quadrangular and narrow in cephalic view, with field of spines well developed; mesial border of cephalic lobe straight, ending proximally in rounded angle covered with spinules, lateral border ending distally in inconspicuous notch. Mesial lobe reduced, spinifom, followed distally by large hooked spine, giving bifid profile to lobe.

Male holotype description. Cervical groove deep, almost straight, ending near lateral margin. Antero-lateral margin without depression behind antero-external orbital angle; 7-8 tubercles before cervical groove, followed by 20 blunt teeth decreasing in size posteriorly. Postfrontal lobes low, wide; median groove absent. Surface of carapace anterior of postfrontal lobes slightly excavated in frontal view, inclined anteriorly. Upper border of front straight in frontal view, slightly bilobed in dorsal view, marked with row of tubercles; lower margin thin, sinuous in frontal view. Surface of front between upper and lower borders high, retracted backwards. Lower orbital margins each with row of tubercles. Surface of carapace smooth, covered by small granules; limit between regions indistinct. Endognath of third maxilliped with external margin rounded, ischium and merus forms internal angle ca. $95^{\circ}$, inner margin of ischium with row of blunt teeth and row of large, thick setae; exognath approximately $0.3 \times$ length of ischium of third maxilliped (figure $1 \mathrm{G}$ ).

First pereiopods heterochelous in both sexes; right cheliped larger than left. Merus with three crests, upper crest with rows of tubercles, internal lower crest with rows of teeth, external lower crest with tubercles. Carpus with tubercles on internal crest and prominent acute distal spine. Inner side of palms of both chelipeds with rows of tubercles; outer side smooth; palm of larger chela (right) not conspicuously

FIG. 1. Fredius granulatus n. sp., holotype male from La Pedrera, Colombia (ICN-MHN-CR 1429): (A), dorsal view of carapace and pereiopods; (B), chela of largest cheliped, external view; (C), carpus of largest cheliped, external view; (D), third maxilliped; (E), second left gonopod. 

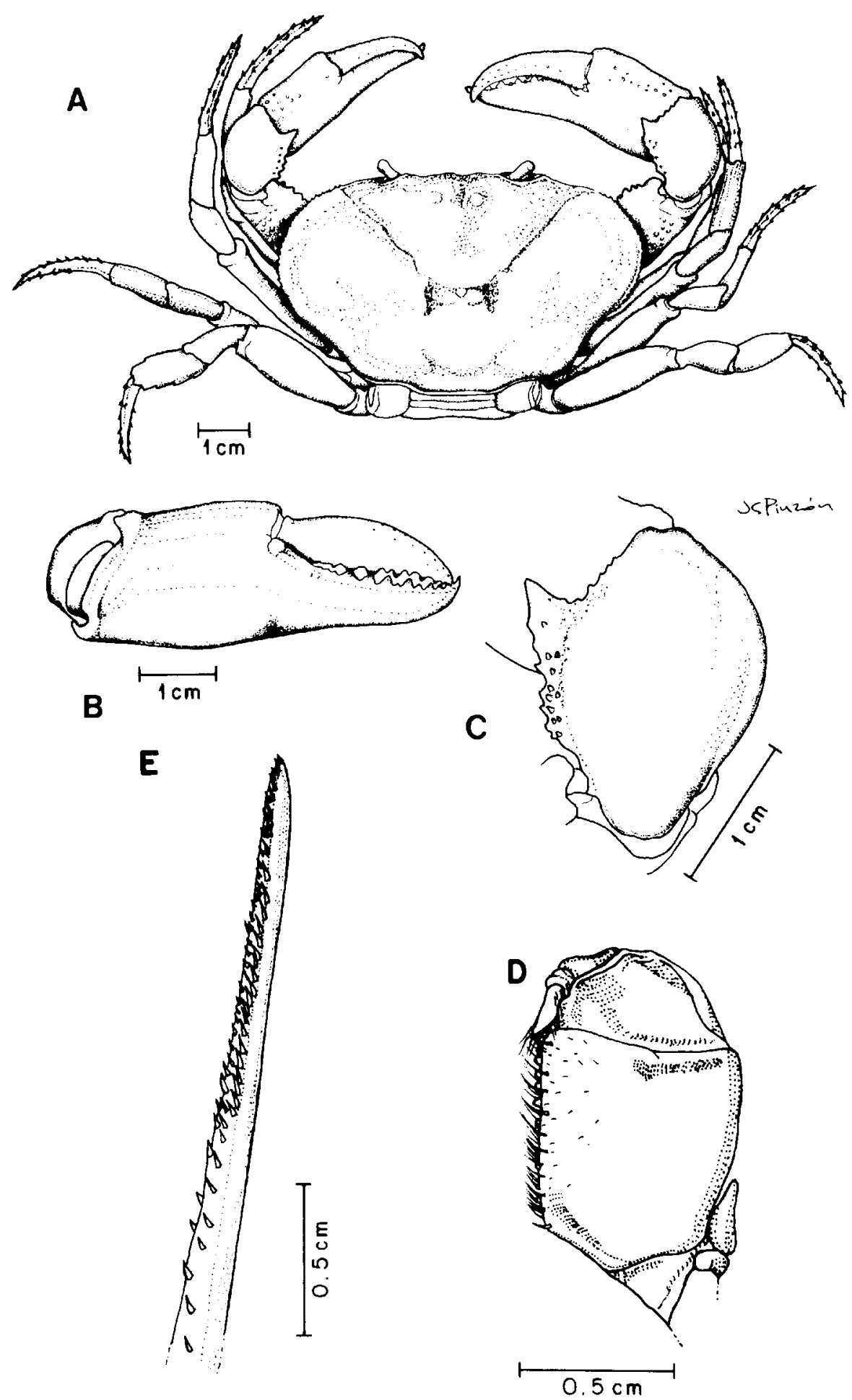

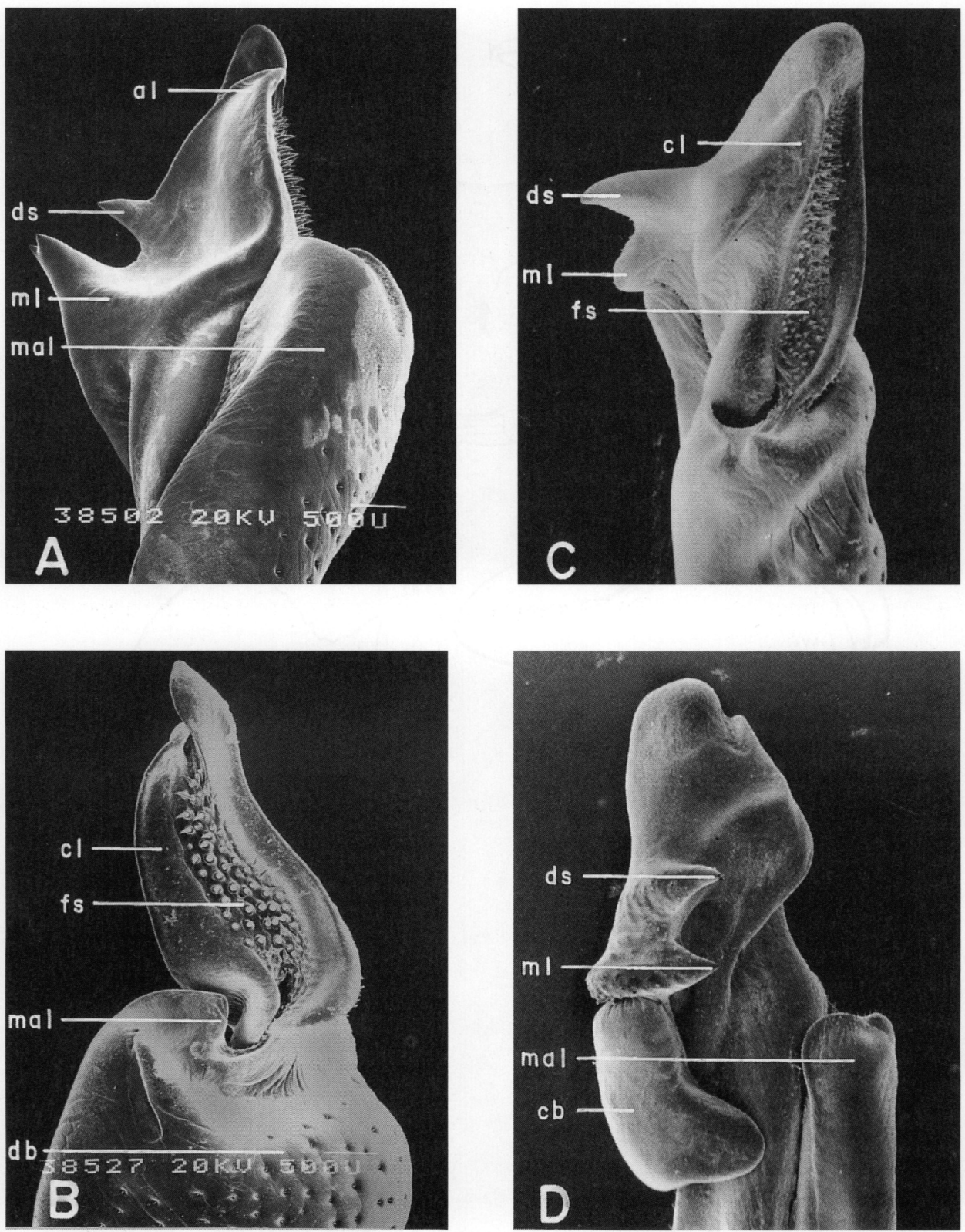

Fig. 2. (A) First male gonopod of Fredius stenolobus (Rodríguez and Suárez, 1994), holotype from Rio Mojagua, Venezuela (IVIC): (A) caudal view; (B) same, lateral view; (C) first male gonopod of Fredius granulatus n. sp., holotype male from La Pedrera, Colombia (ICN-MHN-CR 1429), caudal view; (D) same, cephalic view. al, accessory lobe; cl, cephalic lobe; cb, cephalic bulge; db, distal bulge; ds, distal spine; fs, field of spines; mal, marginal lobe; $\mathrm{ml}$, mesial lobe.

swollen, fingers not gaping when closed, tips crossing; palm of smaller chela not swollen, fingers not gaping when closed, tips crossing. Walking legs (pereiopods 2-5) slender, but not unusually elongated; pereiopods 2 and 3 the longest (length 
$1.17 \times$ breadth of carapace). Dactyli of pereiopods elongated (length $1.5 \times$ length of propodi), those of $\mathrm{P} 2-5$ each with five rows of large spines diminishing in size proximally; spines on dactylus of left third pereiopod arranged as follows: anterolateral and antero-ventral rows with five spines, external row with five spines plus one pair of proximal tubercles, postero-ventral row with three spines, postero-lateral row with four spines.

Male first gonopod thick at base, tapering to subapical prominent bulge that encircles gonopod on cephalic side. Marginal lobe straight, cup-shaped distally. Cephalic lobe straight, quadrangular, narrow in cephalic view, with field of spines well developed; mesial border of cephalic lobe straight, ending proximally in rounded angle covered with spinules, lateral border ending distally in inconspicuous notch. Mesial lobe reduced, spiniform, followed distally by large hooked spine, giving bifid profile to lobe.

\section{Remarks}

The holotype preserved in alcohol is dark brown on the dorsal side of carapace. Walking legs are lighter than carapace, with scattered dark brown specks on the dorsal side. The chelae are dark brown on the upper portions, and red-orange on lateral, and inner surfaces. The ventral surface of the carapace and the appendages are light brown.

The type locality of this new species extends considerably the range of the genus into the upper Amazon basin. The specimens were collected in burrows excavated under tree roots in woodlands. The Indian Makuna communities use these crabs as an important part of their diet.

The specific name refers to the conspicuous granulation of the chelipeds, characteristic of this species.

\section{Other species examined}

The pseudothelphusids grouped under the genus Fredius Pretzmann, 1967, are characterized by an open, flattened, ear-shaped field of apical spines directed cephalad. The list of species as it stands at present is given in table 1. In addition to the new species described above and the seven species listed by Rodriguez and Pereira (1992), the genus also includes the recently described $F$. stenolobus Rodríguez and Suárez, 1994.

The taxonomy of F. reflexifrons (Ortmann, 1897) is quite unsettled (Magalhaes, 1986). For this reason we have restricted here the specific name to the material we

Table 1. Distribution of the species of Fredius listed in chronological order of description.

\footnotetext{
Fredius denticulatus (Milne Edwards, 1853), Atlantic Guianas and Río Negro (Amazon basin)

F. reflexifrons (Ortmann, 1897), French Guiana

$F$. chanffanjoni (Rathbun, 1897), Upper Orinoco and affluents

F. beccarii (Coifmann. 1939), Cuyuni River and Atlantic Guianas

F. estevisi (Rodríguez, 1966), Upper Orinoco and Caroni River

F. fitkaui (Bott, 1969), Rio Negro

F. adpressus Rodríguez and Pereira, 1992, Middle Orinoco basin

$F$. platyacanthus Rodriguez and pereira, 1992, Lpper Caroni River

F. stenolobus Rodríguez and Suárez, 1994, Caura River (Orinoco basin)

$F$ granulatus, new species, Caquetá River (Amazon basin)
} 
examined from St. Eugéne, French Guiana, and used the available specific name F. fittkaui (Bott, 1969) for the material from Rio Negro, Venezuela, listed under $F$. reflexifrons by Rodríguez (1982). Records of $F$. reflexifrons in Rodríguez and Pereira (1992, figure 6) have been omitted. The first gonopod of $F$. beccarii undergoes a considerable transformation during the growth of the individual. In the present study only the characters of the adult of this species have been taken into consideration. Illustrations of the first male gonopods of the species studied can be found in Bott (1969) and Rodríguez and Pereira (1992). Illustrations of the first male gonopods of F. stenolobus Rodríguez and Suárez, 1994, were omitted in the original publication. We give here an SEM of this appendage.

The species of Fredius mentioned above and the subspecies described in the literature, can be discriminated by the following key.

Key to the genus Fredius

1 One spine on surface of caudal lobe

- One or more spines or denticles on distal margin of cephalic lobe . . . . . 7

2 Mesial lobe wide, ending in a single tip or reduced . . . . . . . . . . . 4

- Mesial lobe spiniform, ending in a bifid tip . . . . . . . . . . . . 3

3 Cephalic spine small . . . . . . . . . . . . . . . F. platyacanthus

- Cephalic spine forms a long spur . . . . . . . . . . . F. chaffanjoni

4 Mesial lobe well developed, place at right angle with back surface of cephalic lobe . 5

- Mesial lobe reduced, not forming a right angle with back surface of cephalic lobe . 6

5. Mesial lobe conical . . . . . . . . . . . . . . . F. estevisi estevisi

- Mesial lobe with distal border concave, proximal border convex . F. estevisi siapensis

6 Cephalic spine shorter than accessory lobe. Mesial lobe with a rudimentary spine on distal surface. Cephalic spine and mesial lobe divergent, directed mesially

F. adpressus adpressus

- Cephalic spine of equal length than accessory lobe. Mesial lobe with well developed spine on distal surface. Cephalic spine and mesial lobe parallel, directed upwards

F. adpressus piaroensis

7 Mesial lobe wide, ending in a bifid tip . . . . . . . . . . . . . . . . 8

Mesial lobe reduced, ending in a single tip . . . . . . . . . . . . . . . 9

8 Cephalic lobe narrow . . . . . . . . . . . . . . . F stenolobus

- Cephalic lobe expanded caudally . . . . . . . . . . . . . . F. beccarii

9 Mesial lobe as developed as cephalic spine . . . . . . . . . F. granulatus

- Mesial lobe rudimentary .

10 Cephalic lobe vertical, narrow . . . . . . . . . . . . . . . . . 11

- Cephalic lobe with field of spines greatly distorted, spirally twisted to a transverse position

11 Cephalic lobe with lateral border simple

Cephalic lobe with lateral border forming cup shaped structure

F. denticulatus

F. reflexifrons F. fittkaui

\section{Phylogenetic study}

\section{Methodology for analysis of Fredius}

The strategy used in the cladistic analysis is the same as the one employed in Rodríguez and Pereira (1992), with the same limitations in the number of somatic characters included, due to the uniformity of the carapace and appendages of 
pseudothelphusids. For this reason, the present cladistic analysis is based almost exclusively on the morphology of the first male gonopod where numerous differential characters are found. The only somatic character retained for the analysis is the granulation of the inner side of the palm of chelipeds (character 1 in table 3). The continuity of the antero-lateral margin of carapace with the external orbital angle (character 1 in Rodríguez and Pereira (1992) is an unreliable character due to the high degree of intraspecific variation observed, and consequently it was omitted. The phylogenetic program used was PAUP (Swafford and Begle, 1993).

\section{Homologies in the gonopodal processes}

Characters 2, 3, 5, 6, 7, 8, 9,11,12, 13, 14, 15, 16, and 17 in Rodríguez and Pereira (1992) were included in the present analysis as characters 6, 16, 13, 14, 15, $18,9,22,19,9,3,4,17$, and 2 , respectively although with changes in their definition or polarity in some of them, after a more rigorous study.

The species of Fredius display a progressive torsion of the apex of gonopod in a sinistral direction which results in a displacement of the field of spines from a position facing the latero-cephalic side, to a position facing the meso-cephalic side (character 2). This character was measured observing the gonopod in a distal position and determining the angle between the meso-lateral axis of the appendage and a line normal to the ficld of spines (cephalic lobe axis) (table 2). Two basic groups are present: those species with moderate torsion of the apex (shifted $<90^{\circ}$ from the lateral-cephalic side) and those species exhibiting a high degree of torsion $\left(>90^{\circ}\right)$. The distinction between the two groups was tested using CA Cricket (Polar) Graph for MacIntosh and a crisp partition between them was observed. The first group of species were given state 0 , and the second group state 1 .

In addition to the progressive torsion of the gonopod, the axis of the mesial lobe in all species, except in $F$. estevisi, is displaced from a plane in line with the cephalic lobe to a position directed backwards (character 17). This displacement was measured also by the method described above and similar criteria were adopted for the grouping of values. There is no correspondence between both angles in the majority of species (table 2 ).

One of the most significant homologies of these species regards the presence, shape and position of a spine on the caudal surface of the cephalic lobe (Rodriguez and Percira, 1992; figure 4) or on its distal border (character 12). Other characters

Table 2. Deviation of cephalic lobe axis from caudo-cephalic axis (A) and deviations of the mesial lobe axis from cephalic lobe axis (B) (in degrees) in the species of Fredius.

\begin{tabular}{lrr}
\hline & A & \multicolumn{1}{c}{ B } \\
\cline { 2 - 3 } Fredius platyacanthus & 28 & 45 \\
F. estevisi & 75 & 20 \\
F. granulatus & 78 & 110 \\
F. stenolobus & 78 & 51 \\
F. adpressus & 90 & 105 \\
F. beccarii & 103 & 66 \\
F. reflexifrons & 105 & 103 \\
F. denticulatus & 125 & 80 \\
F. fittkaui & 129 & 101 \\
F. chaffanjoni & 132 & 125 \\
\hline
\end{tabular}


Table 3. Characters of Fredius compared. The first comparison listed for each character is considered to be plesiomorphic.

1 Palm of cheliped (0) no granulated, (1) granulated.

2 Field of spines facing (0) latero-cephalic side, (1) meso-cephalic side.

3 Subapical bulge in cephalic view (0) reduced (1) well developed (2) strongly developed (see Rodríguez and Pereira, 1992, fig. 4I; 4F,M, and 4K,O, respectively).

4 Marginal lobe (0) straight, (1) bent cephalically.

5 Marginal lobe (0) simple, (1) forming strong sinuous bulge

6 Cephalic lobe with field of spines (0) slit-like, (1) open, flat.

7 Cephalic lobe (0) vertical, (1) not vertical.

8 Cephalic lobe with caudal and cephalic plates (0) overlapping, (1) fused

9 Cephalic lobe with lateral border (0) not projected, (1) projected laterally into a caudal spine.

10 Cephalic lobe with lateral border (0) flat, (1) bent over field of spines.

11 Cephalic lobe with lateral border (0) simple, (1) forming cup shaped structure.

12 Cephalic lobe spine or denticles $(0)$ on caudal surface, (1) on distal margin.

13 Cephalic lobe distal margin (0) unarmed, (1) with 1 spine, (2) with several spinules.

14. Cephalic lobe (0) without an accessory lobe, (1) with an accessory lobe.

15 Cephalic spine (0) absent (1), moderately developed, (2) extraordinarily developed.

16 Apical processes of first gonopod (0) not lyrate, (1) forming a lyrate structure with mesial process and accessory spine.

17 Mesial lobe (0) in line with cephalic lobe, (1) bent laterally.

18 Mesial lobe (0) spiniform, (1) a long spur, (2) expanded.

19 Mesial lobe (0) developed, (1) rudimentary.

20 Mesial lobe tip (0) single, (1) bifid

21 Caudal surface of mesial lobe (0) smooth, (1) granulated or spinulous

22 Basal denticle of mesial lobe (0) absent, (1) present.

23 Transverse caudal ridge between mesial lobe and marginal lobe (0) absent, (1) present.

Table 4. Data matrix of 23 characters of the species of Fredius

\begin{tabular}{llllllllllllllllllllllllll}
\hline estev & 0 & 0 & 0 & 0 & 0 & 1 & 0 & 0 & 0 & 0 & 0 & 0 & 0 & 1 & 1 & 0 & 0 & 1 & 0 & 0 & 0 & 0 & 0 \\
adpre & 0 & 0 & 0 & 1 & 0 & 1 & 0 & 0 & 1 & 1 & 0 & 0 & 0 & 1 & 2 & 0 & 1 & 0 & 0 & 0 & 0 & 1 & 0 \\
platy & 0 & 0 & 0 & 0 & 0 & 1 & 0 & 0 & 0 & 1 & 0 & 0 & 0 & 1 & 1 & 0 & 1 & 0 & 0 & 1 & 0 & 0 & 0 \\
chaff & 0 & 1 & 1 & 1 & 0 & 1 & 0 & 0 & 0 & 0 & 0 & 0 & 0 & 1 & 2 & 1 & 1 & 0 & 0 & 1 & 0 & 0 & 0 \\
steno & 0 & 0 & 1 & 1 & 0 & 1 & 0 & 0 & 0 & 0 & 0 & 1 & 1 & 1 & 0 & 0 & 1 & 0 & 0 & 1 & 0 & 0 & 1 \\
becca & 0 & 1 & 1 & 1 & 0 & 1 & 0 & 0 & 0 & 0 & 0 & 1 & 1 & 1 & 0 & 0 & 1 & 2 & 0 & 1 & 0 & 0 & 1 \\
granu & 1 & 0 & 2 & 1 & 1 & 1 & 0 & 1 & 0 & 0 & 0 & 1 & 1 & 0 & 0 & 0 & 1 & 0 & 1 & 0 & 1 & 0 & 0 \\
refle & 0 & 1 & 2 & 1 & 1 & 1 & 0 & 1 & 0 & 0 & 0 & 1 & 2 & 0 & 0 & 0 & 1 & 0 & 1 & 0 & 1 & 0 & 0 \\
fittk & 0 & 1 & 2 & 1 & 1 & 1 & 0 & 1 & 0 & 0 & 1 & 1 & 2 & 0 & 0 & 0 & 1 & 0 & 1 & 0 & 1 & 0 & 0 \\
denti & 0 & 1 & 2 & 1 & 1 & 1 & 1 & 1 & 0 & 0 & 0 & 1 & 1 & 0 & 0 & 0 & 1 & 0 & 1 & 0 & 1 & 0 & 0 \\
pesta & 0 & 0 & 0 & 0 & 0 & 0 & 0 & 0 & 0 & 0 & 0 & 0 & 0 & 0 & 0 & 0 & 0 & 0 & 0 & 0 & 0 & 0 & 0 \\
\hline
\end{tabular}

of the cephalic lobe considered were its position regarding the vertical axis (character 7), the relative fusion of its plates (character 8), and the morphology of its lateral border (characters 10, 11).

The cephalic lobe display in all species a trend towards the development of a granulated surface which in some species extend into the caudal surface of the mesial lobe (character 21). In $F$. beccarii and $F$. stenolobus, this surface presents a transverse ridge. The strong sinuous bulge on the marginal lobe of $F$. stenolobus and $F$. beccarii (character 5) is a plesiomorphy present in several species of the tribe Kingsleyini (Rodríguez, 1982, figure 107), although not so conspicuously developed in Eudaniela pestai (see below). 
In the re-evaluation of characters in $F$. reflexifrons and $F$. fittkaui, the most conspicuous difference is the presence of a cup-shaped structure on the lateral border of the cephalic lobe (character 11) in the latter species, but it was also found that all equivalent characters in both species were more fully developed in $F$. fittkaui. This concern particularly the cephalic spine, which is considered here as homologous with the spine on distal margin of the cephalic lobe rather that with the spine on its caudal surface (character 12).

\section{Out-group selection}

The autapomorphy used to separate the genus Fredius, an open, flattened, earshaped field of apical spines directed towards the cephalic side, differs substantially from the narrow field of spines, frequently slit-like and lodged between two partially or completely fussed lamellae, characteristic of other species of the Tribe Kingsleyini. This last character-state can be considered the primitive condition as it is present in Strengeriana fuhrmanni (Zimmer, 1912), which is regarded as a primitive member of the family (Rodríguez, 1982, p. 32 and figure 10). In the present study, Eudaniela pestai Pretzmann, 1965, was considered as more nearly approaching the ancestral pscudothelphusid condition (see discussion in Rodríguez and Pereira, 1992) and was used as an out-group for the polarization of the characters of the genus Fredius.

\section{Results of the analysis}

The most parsimonious tree found has 36 steps and $\mathrm{CI}=0 \cdot 750$ (figure 3 ). The branch leading to $F$. reflexifrons is zero length, and so the taxa (valid species) is not defined by any autapomorphy. Characters $2,3,13,14,15$, and 20 show homoplasic conditions. The tree starts with the species $F$. estevisi as the most basal taxon, then

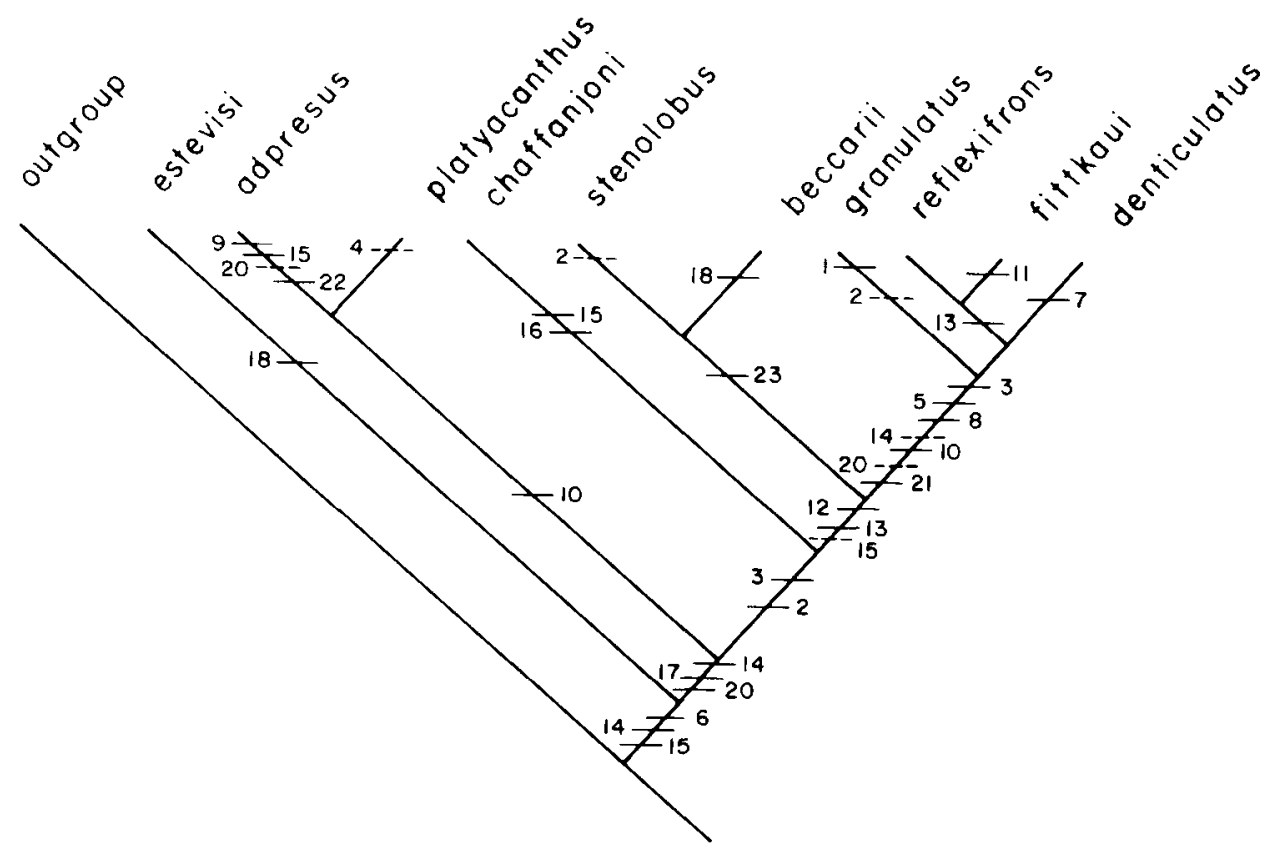

FIG. 3. Most parsimonious cladograms obtained, with indication of the changes in character states. 
follow the pair $F$. adpressus and $F$. platyacanthus, with $F$. chaffanjoni in a rather isolated position. $F$. stenolobus and $F$. beccarii forms a pair, and $F$. granulatus is isolated as a sister taxon for the pair $F$. reflexifrons and $F$. fittkaui. Fredius denticulatus is apparently the most derived taxon.

The autapomorphies that define each cluster are as follows: 18 for $F$. estevisi, 10 for the $F$. adpressus- $F$. platyacanthus cluster; 16 for $F$. chaffanjoni; 23 for the $F$. stenolobus $-F$. beccarii; and 3, 5, 14, 19, and 20 for the rest. Although the cluster most differentiated is the one formed by $F$. granulatus, $F$. reflexifrons, $F$. fittkaui and $F$. denticulatus, these four species could be grouped with $F$. stenolobus and $F$. beccarii by the presence in all of them of a conspicuous and sharply delimited character, as is the armature of the distal border of the cephalic lobe, which can be easily key-out.

The most important difference of our results with the tree obtained by Rodriguez and Pereira (1992) concern the position of $F$. reflexifrons, $\boldsymbol{F}$. denticulatus and $F$. beccarii, which appears in one cluster with $F$. stenolobus, $F$. granulatus, and F. fittkaui in our tree, whereas in the tree chosen as their working hypothesis by these authors, $F$. reflexifrons forms a sister group with $F$. adpressus, and $F$. chanffanjoni appears as a basal clade to these two species rather than grouped basally with $F$. platyacanthus and $F$. estevisi.

\section{Origin and differentiation of the species of Fredius}

The species of Fredius are distributed over a vast territory, with wide disjunctions between them (present records; Bott, 1969; Rodriguez, 1982; Magalhaes, 1986; Rodríguez and Pereira, 1992; Rodríguez and Suárez, 1994). The species are found in four major basins: (1) the Orinoco basin, including the headwaters and tributaries of the Upper Orinoco, the affluents on the right margin of its middle course, and two large tributaries, the Caura and Caroni rivers; (2) the Essequibo-Cuyuni basin, an area of the Venezuelan Guiana separated by low elevations from the Orinoco basin; (3) the Atlantic basin formed by the rivers that run through the territories of Guyana, Suriname and French Guiana, and discharge into the Atlantic; and (4) the Amazon basin as far as the Caquetá River in Colombia (table 1). The Brazo Casiquiare, a natural waterway between the Negro and Orinoco rivers, connect the Orinoco and Amazon basins, while the Essequibo and Cuyuni are connected with the Amazon basin through the inundated areas of the Rupununi. For the rest, the Venezuelan and Atlantic Guianas are separated from the Amazon by continuous mountains chains which are effective barriers to the dispersion of the species of Fredius which are restricted to low altitudes $(<500 \mathrm{~m}$ above sea level).

The largest number of taxa is found in the Venezuelan Guiana, with seven species and subspecies. There is one species in each of the second and fourth regions. The third region has two species with wide distributions: $F$. denticulatus, in the three Atlantic Guianas, and also recorded from the Amazon at Manaos (Magalhães, 1986). The taxonomy of $F$. reflexifrons is not settled, but as it stands at present it possesses the widest distribution for a pseudothelphusid crab, partially overlapping the area of $F$. denticulatus in French Guiana, but also covering the southern basin of the Amazon (Magalhaes, 1986, figure 23).

According to the evidence summarized by Rodriguez and Pereira (1992), the Orinoco basin (ORN) is the oldest geologically, followed by the Essequibo-Cuyuni basin (ESQ-CUY) formed by an early splitting from a once larger Orinoco basin. On the other hand, the part of the lower Amazon valley was formed by alluvionic deposition ranging from Tertiary to Holocene (Grabert, 1983). We can safely say 
that this area is younger than the Orinoco and Cuyuni-Essequibo basin. Finally, the Atlantic area (ATLN), formed mainly by smaller rivers that discharge directly into the Atlantic Ocean, was formed mainly by marine regressions and should be the youngest (Krook, 1979).

Comparison of the relationships provided by the geological data (figure 4) with our hypothesis of relationships within the genus Fredius using Brooks (1990) parsimony analysis show a complete agreement between our phylogenetic data with the area cladogram $(\mathrm{CI}=1 \cdot 0$, figure $5 \mathrm{~A}, \mathrm{~B}$, see table 5 for data). Similar results were obtained by Rodriguez and Pereira (1992) with their own data.

The position of the ancestors within the area cladogram suggests that most of them were present in an hypothetical major basin comprising the present Orinoco, Essequibo and Cuyuni rivers, and much of the evolution of the group occurred there. Ancestors 12, 13, 17, 18 and 20 originated in this area and went into extinction after the splitting of the Essequibo-Cuyuni basin. Ancestor 16 originated in the Amazon area after this was elevated by alluvionic deposition.

Some ambiguity persists about the possible origin of the widespread species $F$. reflexifrons and $F$. denticulatus. Fredius reflexifrons possibly originated from
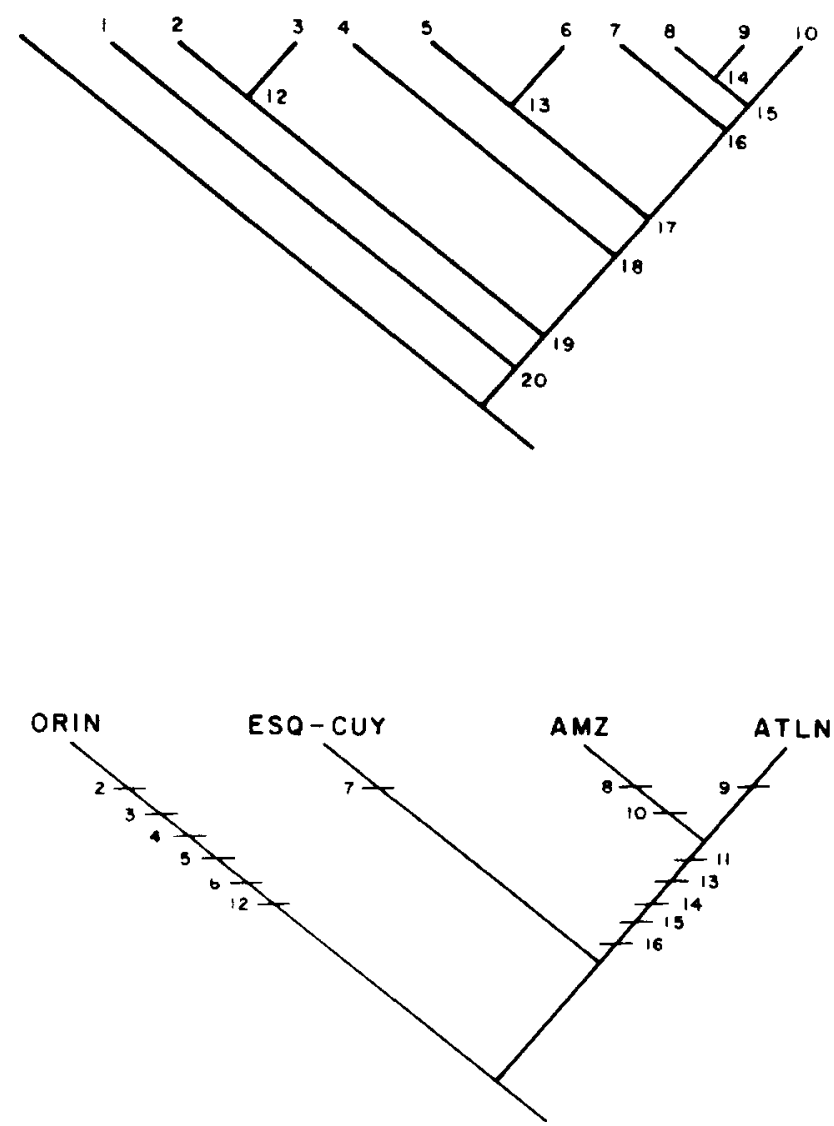

FIG. 4. Tree showing hypothetical relationships of the basins involved in the area of distribution of Fredius. ORIN, Orinoco basin; ESQ-CUY, Essequibo-Cuyuni basin; AMZ, lower Amazon basin; ATLN, Atlantic basin. 


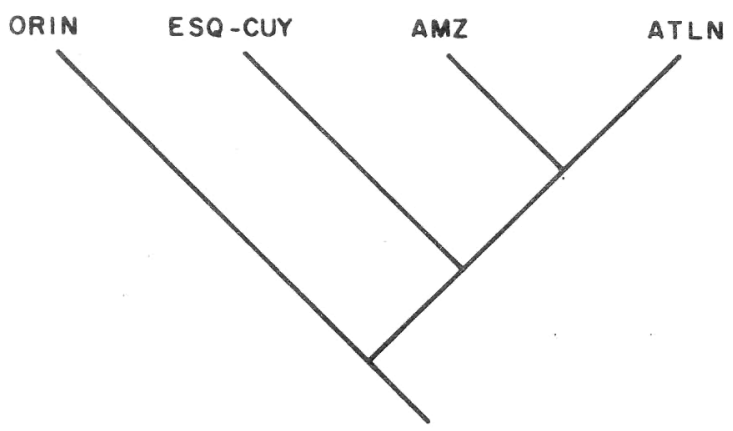

FIG. 5. (A) Most parsimonious cladogram with terminal taxa and internodes numbered; (B) area cladogram based on phylogenetic relationships among seven species of Fredius (based on data coded for Brooks (1990) parsimony analysis) $(\mathrm{CI}=1 \cdot 0)$.

Table 5. Data matrix listing binary codes for species of Fredius inhabiting the four geographic areas. One through 19 refers to species and nodes as listed in tree.

\begin{tabular}{lllllllllllllllllllll}
\hline & 1 & 2 & 3 & 4 & 5 & 6 & 7 & 8 & 9 & 10 & 11 & 12 & 13 & 14 & 15 & 16 & 17 & 18 & 19 \\
\hline ORIN & 1 & 1 & 1 & 1 & 1 & 0 & 0 & 0 & 0 & 0 & 1 & 1 & 0 & 0 & 0 & 1 & 1 & 1 & 1 \\
ESQCU & 0 & 0 & 0 & 0 & 0 & 1 & 0 & 0 & 0 & 0 & 0 & 1 & 0 & 0 & 0 & 1 & 1 & 1 & 1 \\
AMZ & 0 & 0 & 0 & 0 & 0 & 0 & 1 & 0 & 1 & 1 & 0 & 0 & 1 & 1 & 1 & 1 & 1 & 1 & 1 \\
ATLN & 0 & 0 & 0 & 0 & 0 & 0 & 0 & 1 & 0 & 1 & 0 & 0 & 1 & 1 & 1 & 1 & 1 & 1 & 1 \\
\hline
\end{tabular}

ancestor 14 in the Amazon region and then dispersed into the present territory of French Guiana after the marine regression in this area. The most parsimonious explanation for the distribution observed in $F$. denticulatus, as already proposed by Rodríguez and Pereira (1992), is that it originated in the Atlantic drainage and then dispersed into the lower Amazon basin.

\section{Acknowledgements}

The authors thank Hector Suárez for providing the scanning electron micrographs and for his help in the curation of specimens.

\section{References}

Botт, R., 1969, Die Süsswasserkrabben Sud-Amerikas und ihre Stammesgeschichte, Abhandlungen der Senckenbergischen Naturforschenden Gesellschaft, 518, 1-94.

Brooks, D. R., 1990, Parsimony analysis in historical biogeography and coevolution: methodological and theoretical update, Systematic Zoology, 39, 14-30.

GraberT, H., 1983, Des Amazonas-Entwässerungssystem in Zeit und Raum, Geologischen Rundschau, 72, 671-683.

KrooK, L., 1979, Sedimentary petrographic studies in northern Suriname, Thesis, Vrije Universitet Amsterdam (Utrecht: Drukkerij Elinkwijk Bv.), 154 pp.

MaGAlHÃes, C., 1986, Revisão taxonomica dos caranguejos de aguadoce brasileiros da familia Pseudothelphusidae (Crustacea, Decapoda), Amazoniana, 9, 609-636.

NG, P. K. L. and Rodríguez, G., 1996, Freshwater crabs as poor zoogeographical indicators: a critique of Banarescu (1986), Crustaceana, 69, 636-645.

Rodríguez, G., 1982, Les Crabes d'eau douce d'Amerique. Famille des Pseudothelphusidae, Faune Tropicale, 22, 1-223.

Rodríguez, G. and Pereira, G., 1992, New species, cladistic relationships and biogeography of the genus Fredius (Crustacea: Decapoda: Pseudothelphusidae) from South America, Journal of Crustacean Biology, 12, 298-311. 
Rodrígulz, G. and SuÁriz, H., 1994, Fredius stenolobus, a new species of freshwater crab (Crustacea: Decapoda: Pseudothelphusidae) from the Venezuelan Guiana, Proceedings of the Biological Society of Washington, 107, 132-136.

Swafford, D. L. and Begle, D., 1993, PAUP Phylogenetic Analysis Using Parsimony Version 3.1 March 1993. Program users manual. Laboratory of Molecular Systematics, Smithsonian Institution, Center for Biodiversity, Illinois Natural History Survey, USA, $254 \mathrm{pp}$. 